\title{
Mental Nerve Schwannoma - A Rare Cause of Lower Jaw Swelling
}

\author{
Geetha Rajendran ${ }^{1}$, Karthik Ragupathy², Sanjay Pasupathy ${ }^{3}$, Ganesh Ramakrishnan ${ }^{4}$, Kiruthika Shriranjani ${ }^{5}$ \\ 1, 2, 3, 4, 5 Department of Dentistry, Sri Manakula Vinayaagar Medical College \& Hospital, Pondicherry. India
}

\section{INTRODUCTION}

Schwannomas are relatively rare benign neoplasms of neurogenic origin from the neural sheath of peripheral nerves occurring more commonly in the head and neck. Mandibular bone is the commonest site of occurrence of these nerve lesions. Radiographically, intraosseous schwannoma of mandible is very difficult to differentiate from other bony pathologies such as neurofibroma, ameloblastoma, fibrous dysplasia, myxoma, central giant cell lesion, or periapical lesion, so it should be included in the differential diagnosis of lower jaw swelling.

Schwannoma as a pathologic entity was first reported in 1910 by Verocay. Schwannoma (also known as neurinoma, neurolemmoma, neurilemmoma, perineural fibroblastoma, and peripheral nerve sheath tumour) is a rare, slowgrowing, benign neurogenic neoplasm that originated from Schwann cells. Schwann cells cover myelinated sheath of nerve fibres. ${ }^{1}$

These intraosseous schwannomas account for not more than $1 \%$ of the central neoplasms. More than one third of all schwannomas are found in the head and neck region. ${ }^{2}$ Most of these originate from the lower cranial nerve and sympathetic nervous system. Schwannomas from the upper cranial nerves such as trigeminal nerve and its branches are less common. Other commonly reported sites include the vertebra, clavicle, ribs, sacrum, humerus, ulna radius, etc. This painless slow-growing neoplasm may develop at any age.

\section{PRESENTATION OF CASE}

A 24-year-old male patient reported at the Department of Dentistry, Sri Manakula Vinayagar Medical College and Hospital, Pondicherry with the complaint of painless swelling in the left lower jaw since 6 months. Patient's history revealed that the swelling of the left mandible had increased gradually in size since its onset. The jaw swelling was slow growing, painless, without any discharge or paraesthesia. The patient's medical history, drug history, and general physical examination were all non-significant.

On extra oral clinical examination, a diffuse, solitary swelling was evident on the left parasymphysis of mandible that was roughly oval measuring $2.5 \mathrm{~cm} \times 1.5 \mathrm{~cm}$, and the surface of the mucosa appeared smooth. The skin over the lesion appeared intact without any secondary changes. The swelling was bony hard and non-tender (Figure 1).
Corresponding Author: Dr. Karthik Ragupathy 25. Assistant Professor Quarters, Sri Manakula Vinayaagar Medical College \& Hospital Campus. Kalitheerthalkuppam, Pondicherry - 605107, India. E-mail: drsrkarthik@gmail.com

DOI: $10.14260 / \mathrm{jemds} / 2021 / 358$

How to Cite This Article:

Rajendran G, Ragupathy K, Pasupathy $S$, et al. Mental nerve schwannoma - a rare cause of lower jaw swelling. J Evolution Med Dent Sci 2021;10(22):1735-1738, DOI: $10.14260 /$ jemds/2021/358

Submission 26-09-2020,

Peer Review 01-04-2021,

Acceptance 07-04-2021,

Published 31-05-2021.

Copyright (c) 2021 Geetha Rajendran et al. This is an open access article distributed under Creative Commons Attribution License [Attribution 4.0 International (CC BY 4.0)] 


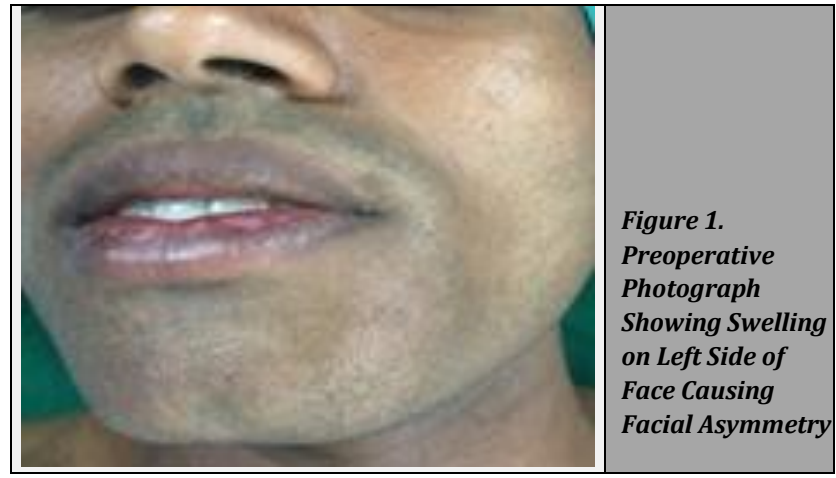

Intraoral examination showed a definite, bony swelling in the buccal vestibule of the left mandible, extended from the left lateral incisor up to the left first molar, measuring $2.0 \mathrm{~cm}$ x 1.5 $\mathrm{cm}$ in size (Figure 2).

The mucosal surface over the lesion appeared smooth and the mucosa surrounding the lesion was normal. On palpation, expansion of buccal cortex with an area of decortications was evident at lower left premolar. The jaw swelling was relatively hard except at the site of buccal decortication. Grade II mobility of the lower left premolar was evident.

The Orthopantomograph had shown a unilocular, well circumscribed radiolucency, measuring approximately $3.0 \mathrm{~cm}$ x $2.5 \mathrm{~cm}$, extending from the mesial margin of the lower left canine up to the mesial root of the lower left first molar tooth (Figure 3). Computed tomography scan revealed buccal cortex expansion and decortication at the region of the lower left premolar on the buccal side (Figure $4 \& 5$ ).

\section{DIFFERENTIAL DIAGNOSIS}

The differential diagnosis included radicular cyst, ameloblastoma, odontogenic keratocyst, Pindborg tumour, and nonodontogenic lesions such as central giant cell granuloma, and central haemangioma, as well as central malignancy such as an osteosarcoma.
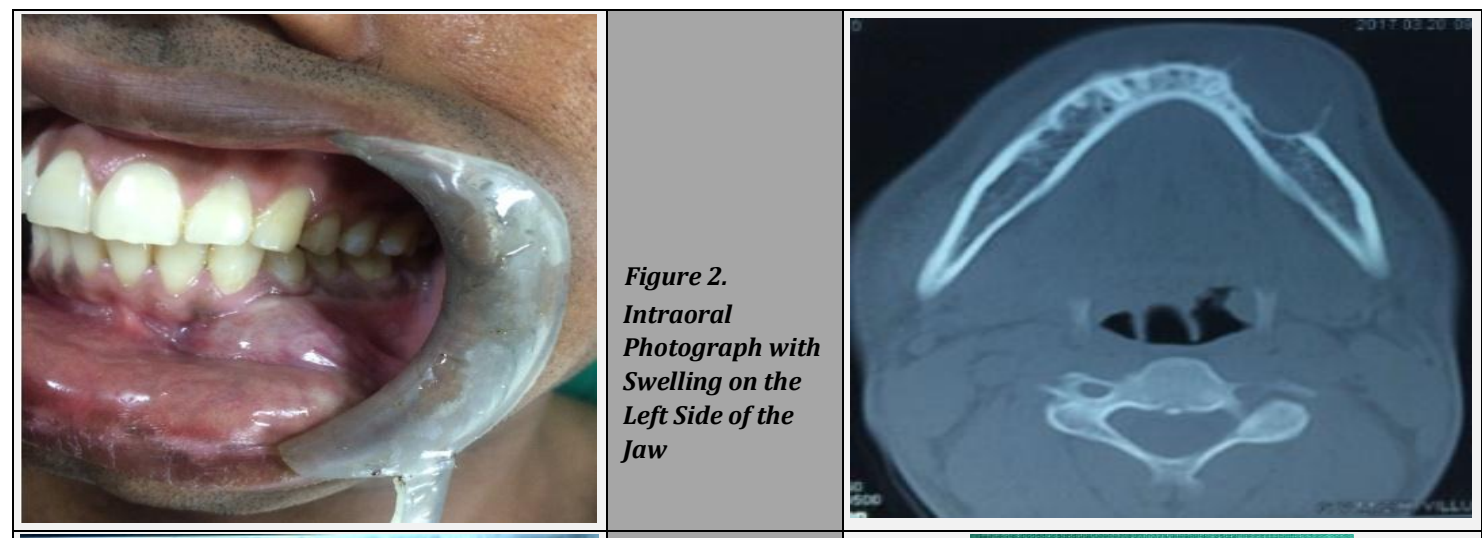

Figure 5.

Axial Computer

Tomographic Image Showing Buccal Cortex Expansion and Decortication within the Left Body of the Mandible

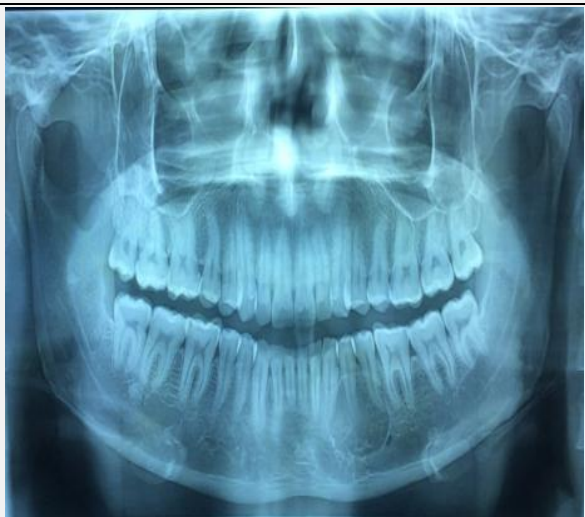

\section{Figure 3.
Ortho- \\ pantomogram with Well Defined Unilocular Radiolucency on the Left Side of Body of the \\ Mandible}

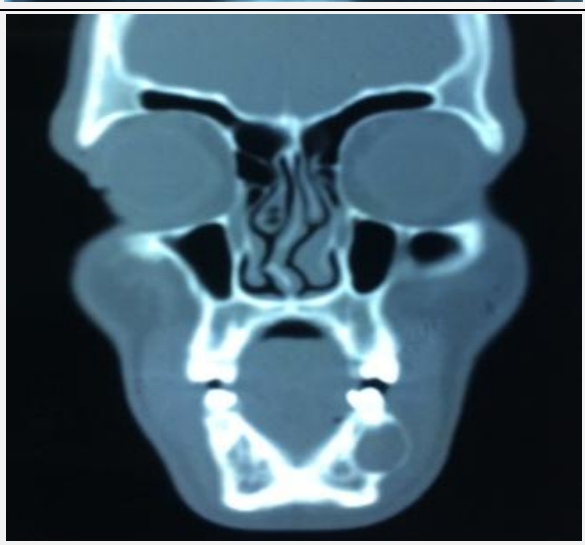

Figure 4. Computer Tomography Image in Coronal Section Showing Cystic Lesions Centrally within the Left Body of the Mandible

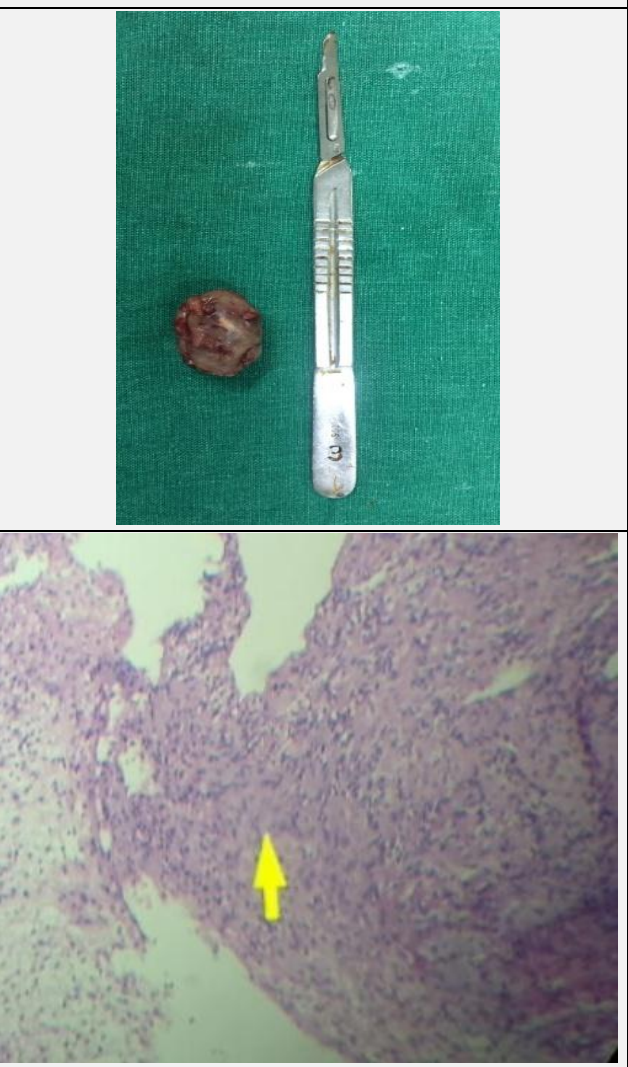

Figure 6.

Excised Tumour

Figure 7.

Photomicrograph Showing Numerous Fascicles of Spindle Cells with Flattened, Tapered Nuclei. Areas of Antoni $A$ Arrangement of Neural Bundles and Verocay Body-like Areas are Also Seen 
Treatment encompassed complete excision of the tumour under general anaesthesia. The histopathological study of excised specimen was carried out, which confirmed the diagnosis (Figure 6). The histopathology of biopsy specimen revealed an unencapsulated neurogenic lesion consisting of polygonal or spindle cells with ample eosinophilic cytoplasm. The underlying matrix was composed of fibrocollagenous and hyalinised areas. Focal areas have shown Antoni A area and Antoni B areas with Verocay bodies (Figure 7). The diagnosis of Schwannoma was confirmed based on histopathological study. The final diagnosis was that of an intraosseous schwannoma arising from the left mental nerve.

\section{DISCUSSION}

This article describes a relatively rare case of primary intraosseous mental nerve schwannoma mimicking a periapical pathology in a 24-year-old male patient which was excised completely following diagnostic histopathological study. While schwannomas of soft tissue are more common finding, intraosseous schwannomas account less than $1 \%$ of the total cases, and are relatively rare in the head and neck region, including the oral cavity. ${ }^{2}$

In terms of their morphology, clinical associations and behaviour, spindle cell tumours are among the most varied of human tumours, entailing an array of frequent misdiagnosis. The origin of these lesions may be attributed to epithelial, mesenchymal and odontogenic components pertaining to the oral cavity. The lesion comprises of neural, muscle, vascular, fibroblastic, myofibroblastic, epithelial, odontogenic and miscellaneous tumors. ${ }^{3}$ It also shows the difficulty in diagnosis of rare bony pathologies when based only on the clinical and radiological findings. This is not surprising because mandibular schwannoma is not generally considered in the differential diagnosis of primary bone tumours involving mandible. 4 Schwannoma was first described in scientific literature in 1910 by Verocay. He coined it neurinoma then. The term neurilemmoma was coined in 1935 by Stout. Schwannomas of the jaw bones are uncommon and intraosseous ones are even rarer. The intraosseous lesions account for less than $1 \%$ of all central neoplasms. ${ }^{5}$

Nerves which are most commonly involved in head and neck schwannomas are the vagus and the cervical sympathetic chain. Trigeminal schwannomas are unusual tumors. ${ }^{6}$ According to the scientific literature, there have been rare cases of intra bony schwannomas that developed in either of the jaw bones. Amongst the jaw bones, the mandible is more commonly involved than the maxilla. Mandibular schwannomas are more commonly involved in the body and ramus of the mandible and can also involve the symphysis region. ${ }^{5}$ The principal features of reported case of mandibular schwannomas are presented in Table 1.1-14 Neurilemmomas are benign, slow growing neurogenic tumours. The main clinical features of schwannoma are slow growing swelling, followed by paraesthesia and pain. Patient may experience pain when the lesion invades the adjacent nerve structure and paraesthesia occurred with Schwannoma originating from the inferior dental canal.

\begin{tabular}{|c|c|c|c|c|c|}
\hline Author (s) & Year & $\begin{array}{l}\text { Patient } \\
\text { Age \& } \\
\text { Gender }\end{array}$ & $\begin{array}{l}\text { Schwannoma } \\
\text { Location in the } \\
\text { Mandible }\end{array}$ & $\begin{array}{c}\text { Surgical } \\
\text { Technique }\end{array}$ & $\begin{array}{c}\text { Follow - } \\
\text { Up } \\
\text { (Months) }\end{array}$ \\
\hline Zainab et al. ${ }^{1}$ & 2012 & $15 / M$ & Left angle and body & $\begin{array}{c}\text { Incisional } \\
\text { biopsy }\end{array}$ & - \\
\hline Sinha et al..$^{3}$ & 2016 & $33 / F$ & Left angle & Excision & 6 \\
\hline N Buric et al. ${ }^{4}$ & 2008 & $23 / F$ & Right body & Excision & 12 \\
\hline Patil et al. ${ }^{5}$ & 2009 & $23 / F$ & Right body & $\begin{array}{l}\text { Segmental } \\
\text { resection }\end{array}$ & - \\
\hline $\begin{array}{l}\text { Mahmood et } \\
\text { al. }{ }^{7}\end{array}$ & 2013 & $23 / F$ & Left angle & Excision & 5 \\
\hline $\begin{array}{c}\text { Vera Sempere } \\
\text { et al. }{ }^{9}\end{array}$ & 2010 & $46 / F$ & Right angle and ramus & Enucleation & 24 \\
\hline $\begin{array}{c}\text { Jahanshahi et } \\
\text { al. }^{10}\end{array}$ & 2011 & $11 / \mathrm{F}$ & Right body and ramus & $\begin{array}{l}\text { Resection of } \\
\text { mandible }\end{array}$ & 3 \\
\hline Shetty et al. ${ }^{11}$ & 2011 & $42 / M$ & Left body and ramus & $\begin{array}{c}\text { Segmental } \\
\text { mandibulectomy }\end{array}$ & 6 \\
\hline $\begin{array}{c}\text { Dagasan VC et } \\
\text { al. }^{12}\end{array}$ & 2018 & $58 / F$ & Right body & Enucleation & 12 \\
\hline Suga et al.13 & 2013 & $33 / \mathrm{M}$ & Left body & Enucleation & 84 \\
\hline Zhang et al. ${ }^{14}$ & 2012 & 35 / M & Right ramus & Enucleation & 36 \\
\hline
\end{tabular}

Schwannomas may involve a bone in three main mechanisms -

1. Schwannoma may originate centrally within a bone,

2. Schwannoma may originate within a nutrient canal, or

3. Soft tissue or periosteal lesion may cause secondary bony erosion and penetration into bone.

The case described in this article demonstrates an intraosseous schwannoma arising centrally within a bone.

Radiographic study revealed, schwannomas of the jaw bones are well-circumscribed, expansile unilocular radiolucency with a sclerotic thin border. ${ }^{7}$ Other radiographic findings such as resorption of root structures, cortical expansion, cortical thinning, and scalloping of peripheral bones can be seen. Additional radiographic imaging methods such as ultrasonography, computerized tomography scan, and magnetic resonance imaging have been advocated to find the extent of the lesion. The differential diagnosis of schwannomas, clinically as well as radiographically, should include periapical lesions, odontogenic cysts and tumours, non-odontogenic tumours, and pseudocysts. 5,10

Microscopically, encapsulation of lesion is a typical feature of schwannomas. ${ }^{11,12}$ The lesion consists of numerous spindle cell bundles in typical Antoni. An area (hypercellularity) and Antoni B area (hypocellularity) arranged in palisading pattern, interspersed in between with small hyaline structures called Verocay bodies. Immunohistochemical study of schwannomas exhibit positive staining for CD34, S - 100 protein and epithelial membrane antigen (EMA). S - 100 protein is immuno positive in all neurogenic tumours. ${ }^{4}$ Schwannomas may exhibit both a benign and a malignant variant. Malignant transformations of schwannomas are rare and still primary malignant form of schwannoma have been reported. ${ }^{14}$

The recommended treatment modality for central schwannomas is surgical excision/resection, with periodical follow ups. ${ }^{8}$ Surgical intervention has the highest efficacy since schwannomas proliferate slowly, they are contained in a welldefined capsule, and they are unresponsive to radiation and chemotherapy. The tumour invaded nerve structures can be sacrificed to avoid the recurrence. Complete excision of the 
lesion with frequent follow up is essential to prevent recurrence of Schwannoma.

\section{CONCLUSION}

We report a relatively rare case of primary intraosseous schwannoma of mental nerve mimicking periapical lesion. Schwannomas generally do not infiltrate the parent nerve. Treatment of choice for Schwannoma is complete surgical excision. Recurrence is unusual and malignant transformation is rare.

\section{Financial or other competing interests: None.}

Disclosure forms provided by the authors are available with the full text of this article at jemds.com.

\section{REFERENCES}

[1] Zainab H, Kale AD, Hallikerimath S. Intraosseous schwannoma of the mandible. J Oral Maxillofac Pathol 2012;16(2):294-6.

[2] Matsuoka Y, Iwamoto A, Yoshida R, et al. A rare intraosseous schwannoma in the maxillary left incisor region: a case report. Journal of Oral and Maxillofacial Surgery, Medicine and Pathology 2020;32(2):114-9.

[3] Sinha R, Kabiraj A, Sarkar S, et al. Intraosseous neurilemmoma of the mandible. J Indian Acad Oral Med Radiol 2016;28(4):441-4.

[4] Buric N, Jovanovic G, Pesic Z, et al. Mandible schwannoma (neurilemmoma) presenting as periapical lesion. Dentomaxillofac Radiol 2009;38(3):178-81.
[5] Patil K, Mahima V, Srikanth H, et al. Central schwannoma of mandible. J Oral Maxillofac Pathol 2009;13(1):23-6.

[6] Agrawal A, Singh V, Rohilla S, et al. Trigeminal schwannoma. Natl J Maxillofac Surg 2017;8(2):149-52.

[7] Mahmood L, Demian N, Weinstock YE, et al. Mandibular nerve schwannoma-resection using sagittal split ramus osteotomy. J Oral Maxillofac Surg 2013;71(11):1861-72.

[8] Deleonibus A, Gharb BB, Papay F, et al. Surgical management of mandibular intraosseous schwannomas. J Craniofac Surg 2017;28(4):e307-11.

[9] Vera-Sempere F, Vera-Sirera B. Intraosseus plexiform schwannoma of the mandible: immunohistochemical differential diagnosis. J Craniofac Surg 2010;21(6):182024.

[10] Jahanshahi G, Haghighat A, Azmoodeh F. Intraosseous neurilemmoma of the mandible: report of a rare ancient type. Dent Res J (Isfahan) 2011;8(3):150-3.

[11] Shetty SR, Rao PK, Chatra L, et al. A case of a massive mandibular schwannoma. J Neurosci Rural Pract 2011;2(1):65-7.

[12] Volkan CD, Guler N, Gulen Z, et al. Intraosseous schwannoma of the mandible. J Dent Res Rep 2018;1(1):1-3.

[13] Suga K, Ogane S, Muramatsu K, et al. Intraosseous schwannoma originating in inferior alveolar nerve: a case report. Bull Tokyo Dent Coll 2013;54(1):19-25.

[14] Zhang L, Xia BQ, Sun H, et al. Intraosseous schwannomas of the jaws: 2 case reports and review of the literature. Oral Surg Oral Med Oral Pathol Oral Radiol 2012;114(6):e13-7. 